\title{
Complementary use of stable isotopes and fatty acids for quantitative diet estimation of sympatric predators, the Antarctic pack-ice seals
}

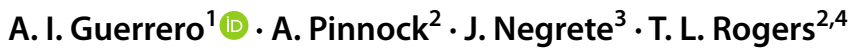

Received: 31 December 2020 / Accepted: 20 September 2021 / Published online: 9 October 2021

(c) The Author(s) 2021

\begin{abstract}
The quantitative use of stable isotopes (SIs) for trophic studies has seen a rapid growth whereas fatty acid (FA) studies remain mostly qualitative. We apply the Bayesian tool MixSIAR to both SI and FA data to estimate the diet of three sympatric predators: the crabeater (Lobodon carcinophaga), Weddell (Leptonychotes weddellii) and leopard seal (Hydrurga leptonyx). We used SI data of their vibrissae and FA data of their outer blubber to produce comparable diet estimates for the same individuals. Both SI and FA models predicted the same main diet components, although the predicted proportions differed. For the crabeater seal, both methods identified krill, Euphausia superba, as the main, and almost exclusive, food item, although the FA model estimated a slightly lower proportion, potentially due to the low lipid content of krill compared to the fish species used in the model. For the Weddell seal the FA model identified the fish Pleuragramma antarcticum as the most important prey, whereas the SI model was not able to distinguish among prey species, identifying a 'fish-squid' group as the main diet component. For the leopard seal, both models identified krill as the main contributor; however, the predicted proportions for the secondary sources differed. Although vibrissae and outer blubber may not represent the same timeframe, the use of MixSIAR with FA data provides diet estimates comparable to those obtained with SI data, thus, both approaches were complimentary. The use of both biotracers offers a feasible option to study diets of wild animals in a quantitative manner.
\end{abstract}

Keywords Biochemical tracer $\cdot$ Blubber $\cdot$ Marine mammal $\cdot$ Pinniped $\cdot$ Trophic marker

\section{Introduction}

The study of marine predators is particularly challenging due to low encounter rates and laborious handling of wild animals. Until a few decades ago, our understanding of their

Communicated by Helene Marsh.

A. I. Guerrero

alicia.guerrero@uv.cl

1 Centro de Investigación y Gestión de Recursos Naturales (CIGREN), Instituto de Biología, Facultad de Ciencias, Universidad de Valparaíso, Gran Bretaña 1111, Playa Ancha, Valparaíso, Chile

2 Evolution and Ecology Research Centre, School of Biological, Earth and Environmental Sciences, University of New South Wales, Sydney 2052, Australia

3 Instituto Antártico Argentino, Cerrito 1248, C10140 AAZ Buenos Aires, Argentina

4 Centre for Marine Science and Innovation, School of Biological, Earth and Environmental Sciences, University of New South Wales, Sydney 2052, Australia ecology consisted of limited observations as they came ashore or near the surface. Traditionally, we have relied on methods such as stomach and scat content analyses to study their foraging ecology (Hall-Aspland and Rogers 2004; Acevedo et al. 2015). Although these techniques provide valuable information, they are usually based on few and recent feeding events, and have known biases related to identification of prey items and differential digestion rates (Gales and Cheal 1992), making it difficult to answer complex ecological questions.

The implementation of new methods such as satellite transmitters and biochemical analyses has allowed to substantially broaden our knowledge of the behaviour and foraging ecology of marine predators (Iverson et al. 1997). Biochemical methods, such as fatty acid (FA) and stable isotope (SI) analyses, can reconstruct diets by overcoming the caveats of the traditional techniques. These two biochemical methods are based on the principle that an animal's diet is reflected in the patterns of FAs and SIs of their tissues (Hooker et al. 2001; Guerrero et al. 2020). Many FAs, particularly polyunsaturated FAs, can only be synthesized at 
low trophic levels and are transferred to higher trophic levels with minimal modification (Iverson 1993) and thus, can be used to distinguish dietary preferences (Dalsgaard et al. 2003; Guerrero et al. 2020). Similarly, the isotopic composition of an animal's tissues is correlated with those of its prey items and change in a predictable way between trophic levels (Gannes et al. 1997; Hückstädt et al. 2012). Thus, these biochemical compounds have the potential to be used as biological tracers ("biotracers").

Although these two methods have been widely used as dietary predictors, there has been controversy regarding their actual accuracy in predicting diet when used alone (Gannes et al. 1997; Grahl-Nielsen et al. 2011; Rosen and Tollit 2012). Limitations to the use of FAs as biotracers include the difficulty of tracing FAs in upper trophic levels, because they typically originate from a variety of sources and thus they become obscured as they travel up the food web (Dalsgaard et al. 2003; Wheatley et al. 2007). In addition, many of these FAs have specific physiological functions (Alonzo et al. 2005); therefore, their abundance in the tissues can vary according to the animal's physiological state. Similarly, the use of SIs has constraints such as the limited number of variables (e.g. carbon and nitrogen) used for dietary predictions, which limits the applicability of some statistical models as usually only a corresponding number of prey items can be incorporated into the analysis (Bromaghin 2017). It is usual that several prey species share similar SI values and therefore they need to be combined into a single prey group (e.g. Hückstädt et al. 2012; Goetz et al. 2016; Botta et al. 2018); making it difficult to obtain a good taxonomic resolution of the predator's diet (Guerrero and Rogers 2020). Considering these limitations, the combined use of these two biotracers has been proposed as a more accurate technique to estimate diet composition (Dalsgaard et al. 2003).

Despite having a predominantly qualitative focus, trophic studies based on FA data have enabled the understanding of energy flow within food webs (e.g. Beck et al. 2007; McMeans et al. 2012; Guerrero et al. 2016). More recently, efforts have concentrated on developing robust biotracerbased quantitative methods to obtain accurate estimates of a predator's diet (Goetsch et al. 2018).

The Bayesian mixing model tool MixSIAR (Stock et al. 2018), although originally developed for SI data, can be applied to other mixing processes, as it estimates the contribution of different sources (prey) to a mixture (consumer). However, its use with FA data has received less attention compared to SI data. Guerrero and Rogers (2020) tested the performance of MixSIAR with FA data for diet estimation of captive animals undergoing feeding experiments, including different consumer species such as fish, birds and marine mammals, with different diet compositions. MixSIAR accurately estimated consumers' main dietary items, and identified shifts in diet and absent prey (Guerrero and Rogers
2020). To date, however, MixSIAR has not been used to study the diet of wild animals based on their FAs. Here, we implement the MixSIAR approach with paired FA and SI data from wild animals. The aim of this study is to evaluate how FAs and SIs perform relative to each other in predicting diet composition of three predators within the Antarctic ecosystem.

We estimated the diet composition in three sympatric Antarctic pack-ice seals: the leopard (Hydrurga leptonyx), crabeater (Lobodon carcinophaga) and Weddell seal (Leptonychotes weddellii), using FAs from their outer blubber, and SIs from their whiskers. These top predators inhabit the western Antarctic region, that is being dramatically affected by climate change, which is in turn shaping ecosystem dynamics (Clarke et al. 2007). Predators can evidence changes in the distribution, abundance, and composition of the prey community (Hazen et al. 2019). Quantitative data of their foraging behaviour is, therefore, important to understand and monitor ecosystem status, and predict potential changes (Fleming et al. 2016).

Leopard seals feed on a variety of prey at different trophic levels, such as krill, fish, penguins and other seals (Siniff and Stone 1985; Green and Williams 1986; Rogers and Bryden 1995; Hall-Aspland and Rogers 2004; Casaux et al. 2009; Botta et al. 2018; Krause et al. 2020); whereas crabeater seals specialise almost exclusively on krill (Laws 1977; Hückstädt et al. 2012), and Weddell seals prey mostly on fish, but also on cephalopods (Burns et al. 1998; Zhao et al. 2004; Casaux et al. 2011; Acevedo et al. 2015; Goetz et al. 2016). Thus, we evaluated how the combined use of FAs and SIs performs to estimate the relative dietary composition of predators with different foraging strategies.

\section{Methods}

\section{Sample collection of seals}

During the austral summer of 2015, 21 crabeater seals (10 adult males, 9 adult females, and 2 juvenile females), 18 Weddell seals ( 6 adult males and 12 adult females) and 13 leopard seals (10 adult males, 2 adult females, and 1 juvenile male) were sampled while hauled out on sea ice off the Danco Coast, Western Antarctic Peninsula (640' ${ }^{\prime}$ S 60 $57^{\prime}$ W). Seals were immobilised using Zoletil (tiletamine/zolazepam, Virbac) delivered via a Tele-inject air gun darting system (Higgins et al. 2002). All applicable institutional guidelines for the care and use of animals were followed. The immobilisation and sampling of seals in the Antarctic Specially Protected Area No. 134 was approved by the Dirección Nacional del Antártico, Buenos Aires, Argentina; and performed according to the SCAR code of conduct for animal experiments under UNSW Animal Care and Ethics 
Committee (Approval 15/55A). Following immobilisation, one whisker was plucked and an $8 \mathrm{~mm}$ diameter biopsy sample collected from the mid-dorsal region to a depth that incorporated the outer blubber and the skin. Skin and outer blubber layer were separated and stored in airtight vials at $-20{ }^{\circ} \mathrm{C}$.

\section{Sample and data collection of prey}

Antarctic krill, Euphausia superba, samples were obtained opportunistically from stomachs of deceased leopard seals in 2008; and from stomachs of gentoo, Pygoscelis papua, and chinstrap, P. antarcticus, penguins in 2015. Muscle samples of adult gentoo penguins were collected opportunistically in 2008 and 2012, in the same study area, from fresh carcasses found in the vicinities of penguin colonies. All these samples were analysed for FAs only, following the corresponding procedure described further below.

SI values and other FA values for potential prey were obtained from the published literature (see Table 1). We used the same prey species for both FA and SI models, except for the cephalopod species, where we used Moroteuthis ingens for the FA model and Pareledone sp for the SI model. For the Antarctic fur seal, Arctocephalus gazella, we used milk FAs and SIs, as muscle or blubber samples were not available. Table 2 shows the prey species included in the models to estimate the diet of each seal species.

\section{Fatty acid analysis}

Total lipid of seal blubber, whole krill, and penguin muscle, was extracted following a modified Folch et al. (1957) method (Budge et al. 2006). Briefly, approximately $0.2-0.5 \mathrm{~g}$ of tissue was extracted using 2:1 chloroform: methanol with $0.01 \%$ of butylated hidroxytoluene, washed in a salt solution, centrifuged, dried over anhydrous sodium sulphate and evaporated under nitrogen. FA methyl
Table 2 Source (prey) species used to estimate the diet of each consumer (seal)

\begin{tabular}{llll}
\hline Consumer & Prey taxon & Sources & \\
\cline { 3 - 4 } \cline { 3 - 3 } Crabeater seals & Krill & E. superba & E. superba \\
& Fish & E. carlsbergi & E. carlsbergi \\
& Fish & E. antarctica & Pa_Ea ${ }^{\mathrm{a}}$ \\
& Fish & P. antarcticum & \\
Leopard seals & Seal & A. gazella & A. gazella \\
& Krill & E. superba & E. superba \\
& Fish & P. antarcticum & P. antarcticum \\
& Penguin & P. papua & P. papua \\
& Cephalopod & M. ingens & Pareledone sp. \\
Weddell seals & Krill & E. superba & E. superba \\
& Fish & G. nicholsi & G. nicholsi \\
& Fish & E. antarctica & Pa_Ea_P \\
& Fish & P. antarcticum & \\
& Cephalopod & M. ingens & \\
\hline
\end{tabular}

The group "Pa_Ea" correspond to the combined isotopic values of the fish $P$. antarcticum and E. antarctica, and the group "Pa_Ea_P" is the combination of these two fish species and the squid Pareledone sp

${ }^{\mathrm{a}}$ Group of combined species

esters were prepared using $\mathrm{H}_{2} \mathrm{SO}_{4}$ in methanol and then extracted into hexane $(50 \mathrm{mg} / \mathrm{ml})$.

Gas chromatography analyses were performed with Agilent 7890A Series GC System (Agilent Technologies, USA) equipped with a flame ionization detector, as described in Guerrero and Rogers (2017). Identification of FAs and isomers was conducted using known standard mixtures (Nu Check Prep., Elysian, MN, USA). Once FAs were identified, their concentrations were converted to percentage contributions of the total FAs.
Table 1 Literature sources for each prey species used in diet estimation models

\begin{tabular}{lll}
\hline Species & Citation & \\
\cline { 2 - 3 } & Fatty acid data & Stable isotope data \\
\hline Euphausia superba & $\begin{array}{c}\text { Fricke et al. (1984), Phleger et al. } \\
(2002), \text { this study }\end{array}$ & $\begin{array}{c}\text { Polito and Goebel } \\
(2010), \text { Polito et al. }\end{array}$ \\
& & $(2011)$ \\
Electrona carlsbergi & Stowasser et al. (2009) & Polito and Goebel (2010) \\
Electrona antarctica & Stowasser et al. (2009) & Polito and Goebel (2010) \\
Pleuragramma antarcticum & Hagen et al. (2000) & Polito et al. (2011) \\
Arctocephalus gazella & Iverson et al. (1997) & Polito and Goebel (2010) \\
Pareledone sp. & - & Mincks et al. (2008) \\
Pygoscelis papua & This study & Polito et al. (2011) \\
Moroteuthis ingens & Phillips et al. (2001) & - \\
Gymnoscopelus nicholsi & Stowasser et al. (2009) & Stowasser et al. (2012) \\
\hline
\end{tabular}




\section{Stable isotope analysis}

Prior to analysis, whiskers were cleaned in chloroform:methanol $(2: 1 \mathrm{v} / \mathrm{v})$ in an ultrasonic bath and allowed to air dry for at least $48 \mathrm{~h}$. Whiskers were sectioned into $2 \mathrm{~mm}$ subsamples of $0.2 \pm 0.1 \mathrm{mg}$ and placed into tin capsules for analysis. For diet estimation using MixSIAR, we used a mean isotope value of the whole whisker for each consumer.

Whisker samples were analysed using a Flash 2000 organic elemental analyser (ThermoFisher Scientific) interfaced to a Delta V Advantage Isotope Ratio Mass Spectrometer via a ConFlo IV interface (Bioanalytical Mass Spectrometry Facility, UNSW, Australia).

Stable carbon and nitrogen-isotope ratios are reported as $\delta^{13} \mathrm{C}$ and $\delta^{15} \mathrm{~N}$, respectively, in parts per thousand (\%o):

$\delta^{13} \mathrm{C}$ or $\delta^{15} \mathrm{~N}(\% o)=\left[\left(R_{\text {sample }} / R_{\text {standard }}\right)-1\right] \times 1000$,

where $R$ is the ratio of the heavier isotope to the lighter isotope $\left({ }^{13} \mathrm{C} /{ }^{12} \mathrm{C}\right.$ or $\left.{ }^{15} \mathrm{~N} /{ }^{14} \mathrm{~N}\right)$. The standards correspond to Vienna-Peedee belemnite (V-PDB) for carbon, and atmospheric nitrogen for nitrogen, reference standard of nitrogen and carbon, Glutamic 40 and Glutamic 41, were included after every 10 samples to account for machine drift.

\section{Diet estimation}

Three datasets are necessary to estimate diet using Bayesian mixing models: signatures of consumers (predator), signatures of sources (prey) and values of trophic discrimination (differences in biotracer values between prey and predator). We used the discrimination values $2.2 \pm 0.7 \%$ ofor $\delta^{13} \mathrm{C}$ and $3.5 \pm 0.6 \%$ o for $\delta^{15} \mathrm{~N}$, obtained by Newsome et al. (2010) for the sea otter, Enhydra lutris.

The equivalent to discrimination values for FA data are calibration coefficients, which are used to account for selective FA metabolism and hence changes in the predator's FA proportions relative to diet consumed (Iverson et al. 2004; Guerrero and Rogers 2020). We used the calibration coefficients derived from captive harbour seals, Phoca vitulina, fed herring for over a year (Rosen and Tollit 2012), and applied them to our three study species. Prior to the Bayesian mixing model analysis, the FA signatures of prey items were multiplied by the calibration coefficients of harbour seals; thus, taking prey signatures to the predator space (Bromaghin 2017; Guerrero and Rogers 2020). This was done prior to analysis since MixSIAR treats discrimination as additive values, whereas FA calibration coefficients are multiplicative values. Therefore, as the prey values already accounted for the 'enrichment' in FA proportions, we then set discrimination values to zero.
For diet estimation analyses, we used dietary and extended dietary FAs, according to Iverson et al. (2004), but discarded those FAs with high calibration coefficients $(>3)$, since they indicate greater influence of consumer metabolism or preferential accrual rather than a reflection of diet (Guerrero and Rogers 2020). Thus, the number of FAs used for analyses, for each consumer species, was 12 .

MixSIAR requires sources values to be statistically different. Therefore, prior to analysis, we tested the differences in biotracer values among sources both visually and statistically. For each FA model, we conducted a Non-metric multidimensional scaling (NMDS) analysis to visually assess differences among sources. For each SI model, we produced a biplot to assess visual differences among sources. For statistical confirmation, we conducted pairwise multilevel comparisons in the R package "pairwiseAdonis" (Martinez Arbizu 2017), which is based on the adonis function of the R package "vegan" (Oksanen et al. 2018) that implements a multivariate analysis of variances using distance matrices. When sources were not statistically different from each other, they were combined into a single group based on the similarity of their biotracer values.

We used the Bayesian mixing tool MixSIAR (Stock et al. 2018) for both FA and SI data. To run the model, biotracer values for each consumer were input as raw data. Biotracer values for each source were input into the model as the mean and standard deviation. For both FA and SI data, we used non-informative priors. We used multiplicative process error structure (Stock and Semmens 2016) and model convergence was assessed via Gelman-Rubin and Geweke diagnostics (Geweke 1991; Gelman et al. 2014).

Data analyses were conducted using RStudio software, version 1.1.456 (RStudio Team 2016). Posterior distributions obtained from the MixSIAR analyses are expressed as median (and range).

\section{Results}

The NMDS analysis of individual animals showed three distinct groups that represented the three species. Leopard and crabeater seals were closer to each other in the plot, indicating more similarity in their FA profiles (Fig. 1a). Similarly, the isoplot (Fig. 1b) showed the three species as separate groups, although there was overlap between the crabeater and leopard seals. Crabeater seals had the lowest $\delta^{13} \mathrm{C}$ and $\delta^{15} \mathrm{~N}$ values whereas Weddell seals had the highest isotopic values, indicating higher trophic position.

\section{Diet estimation for crabeater seals}

Prey species used to estimate the diet of crabeater seals via FAs were statistically different from each other $\left(F_{3}=90.78\right.$, 

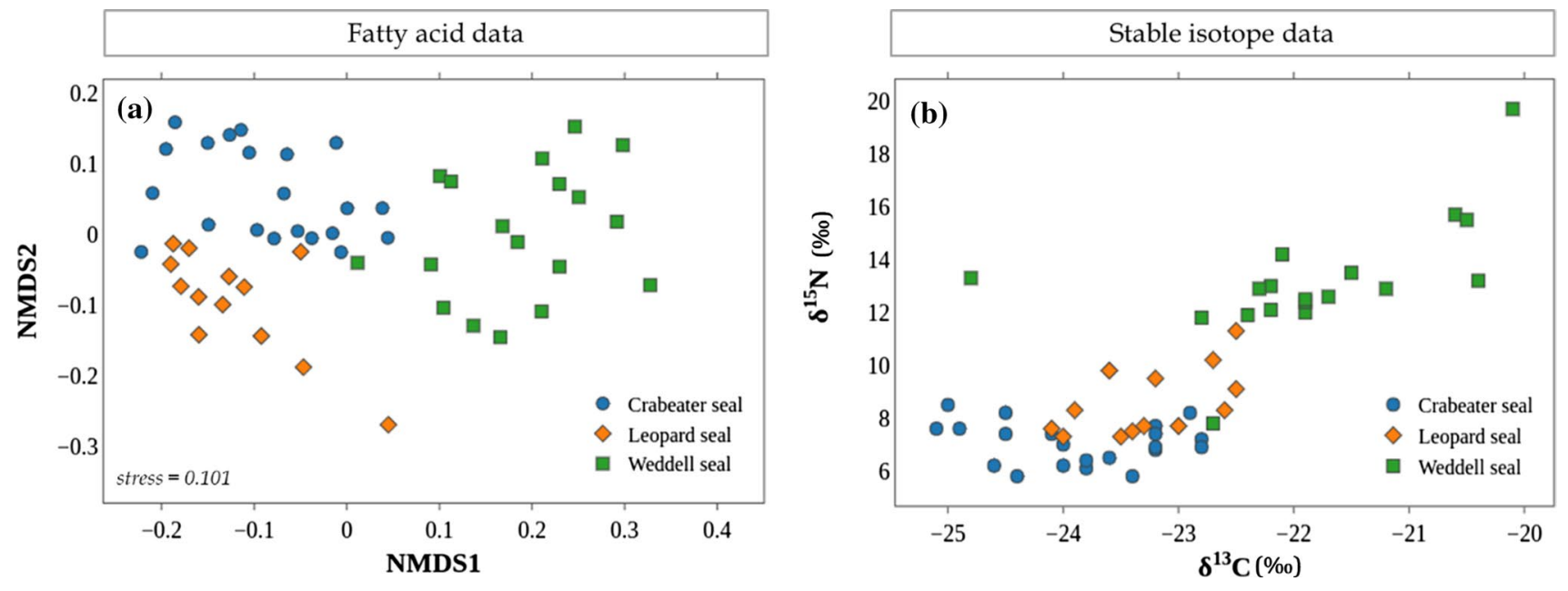

Fig. 1 Biplots for biotracer values of crabeater $(n=21)$, Weddell $(n=18)$ and leopard seals $(n=13)$ : a non-metric multi-dimensional scaling (NMDS) plot of the blubber FA profiles, and $\mathbf{b}$ biplot of the isotopic values of whiskers

$P=0.001$, Fig. 2a), therefore, all four species were input into the model. For SI-based estimations, although the groups were different $\left(F_{3}=209.44, P=0.001\right)$, pairwise comparisons revealed that the fish species $P$. antarcticum and $E$. antarctica were not statistically different $\left(F_{1}=1.01\right.$, adjusted $P=1.00$, Fig. 2b), hence, they were combined into a single group named "Pa_Ea" (Table 2).

Both biotracers identified krill, E. superba, as the main component of the diet of crabeater seals. The FA model estimated that E. superba contributed $84 \%$ to the diet, whereas the SI model determined that E. superba contributed $91 \%$ (Table 2, Fig. 3). The FA model estimated that E. antarctica was the most important fish species, with $11 \%$ of

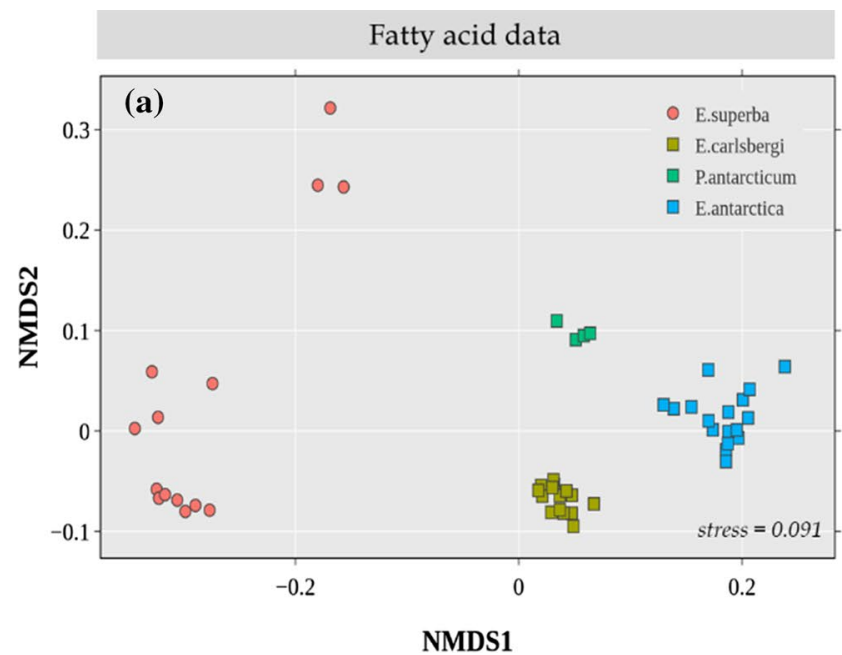

Fig. 2 Biplots for biotracer values of source species used to estimate the diet of crabeater seals: a Non-metric multi-dimensional scaling (NMDS) plot of their FA profiles, and $\mathbf{b}$ biplot of their isotopic values. Square symbols represent fish species, whereas the circle symbol contribution, however the SI model attributed almost equal importance to all fish species/groups (4\% each).

\section{Diet estimation for Weddell seals}

Due to lack of biotracer data, we used the cephalopod $M$. ingens for FA models and Pareledone sp. for SI models. As the sources used for diet estimation of Weddell seals had different FA profiles ( $F_{4}=96.90, P=0.001$, Fig. $\left.4 \mathrm{a}\right)$ we used all five source species in the FA model (Table 2). Based on SI values, the groups were different overall $\left(F_{4}=183.56\right.$, $P=0.001$, Fig. 4b), although pairwise comparisons show that there were no differences between the fish species $P$.

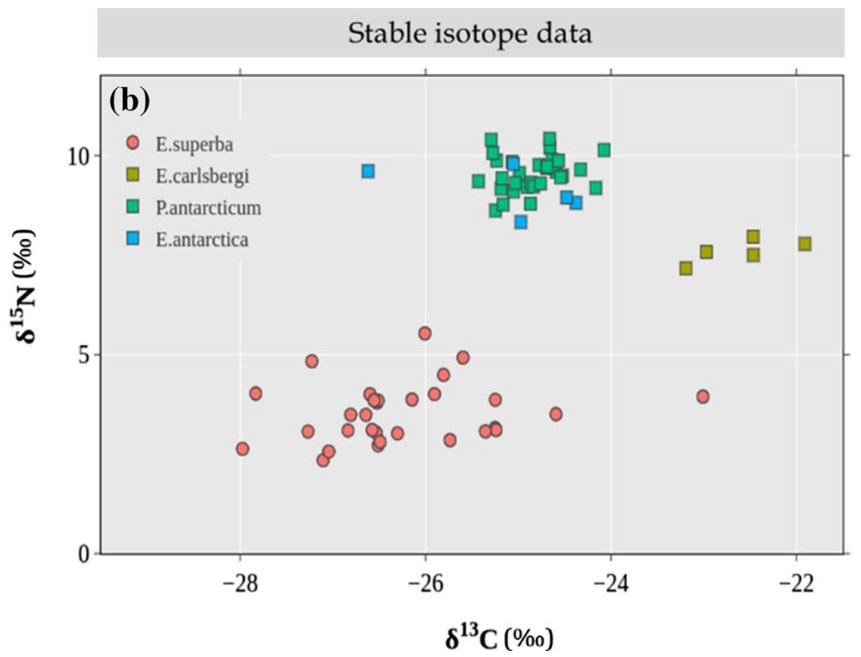

is krill. Because of the isotopic similarity between the fish species $P$. antarcticum and E. antarctica, they were later combined into a group named $P a \_E a$ for diet estimation 

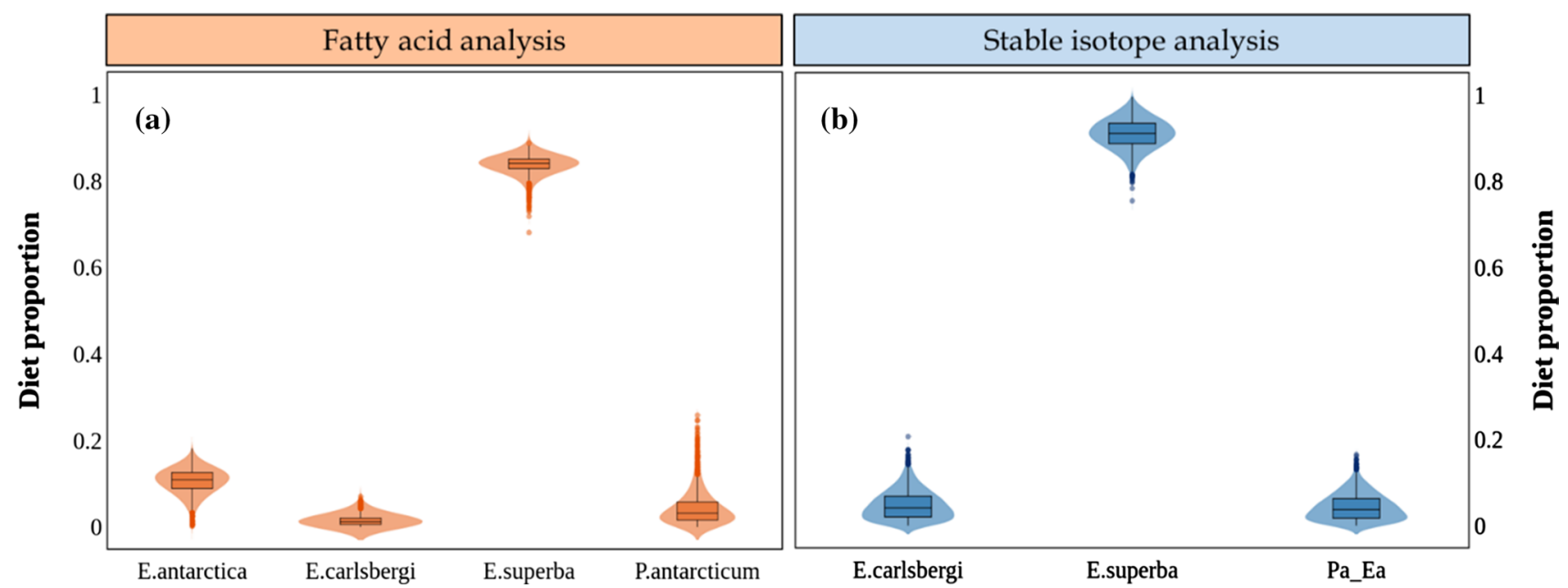

Fig. 3 Diet estimation for crabeater seals $(n=21)$ using the Bayesian mixing model MixSIAR, based on a fatty acid or $\mathbf{b}$ stable isotope data. The prey "Pa_Ea" corresponds to the isotopic values of $P$. antarcticum and E. antarctica combined into a single group, due to their isotopic similarity

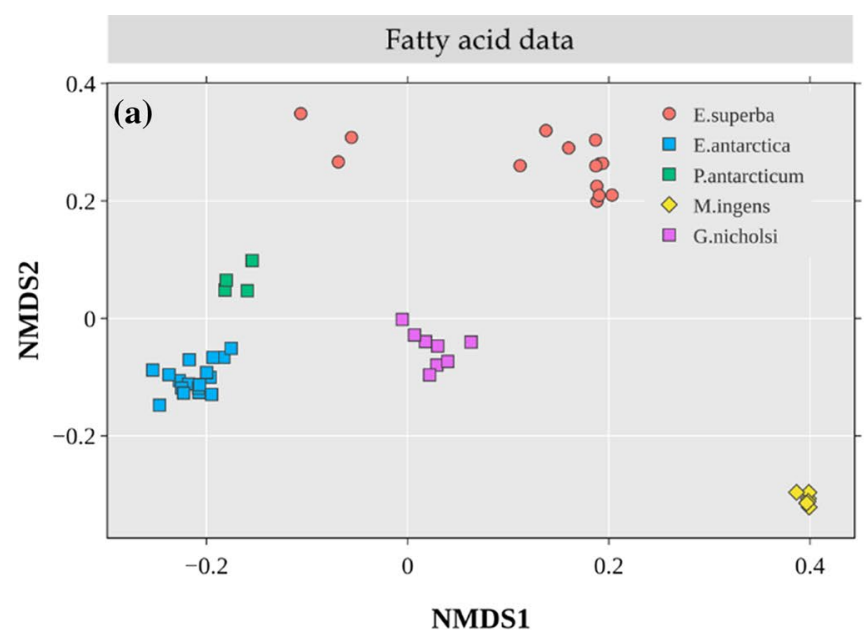

Fig. 4 Biplots for biotracer values of source species used to estimate the diet of Weddell seals: a non-metric multi-dimensional scaling (NMDS) plot of their FA profiles, and b biplot of their isotopic values. Square symbols represent fish species, the diamond symbol rep-

antarcticum and E. antarctica $\left(F_{1}=1.01\right.$, adjusted $\left.P=1.00\right)$, between E. antarctica and the cephalopod Pareledone sp. $\left(F_{1}=1.27\right.$, adjusted $\left.P=1.00\right)$, and between $P$. antarcticum and Pareledone sp. $\left(F_{1}=4.95\right.$, adjusted $\left.P=0.20\right)$, therefore these three species were combined into a group, named "Pa_Ea_P" (Table 2).

Based on FA data, MixSIAR estimated that $66 \%$ of the diet of Weddell seals was composed of $P$. antarcticum, followed by $24 \%$ of G.nicholsi, $8 \%$ of E. superba, whereas $E$. antarctica and the squid M. ingens were negligible (Table 3, Fig. 5a). Based on SI data, the estimated main component of the diet of Weddell seals was the group Pa_Ea_P, with 72\%,

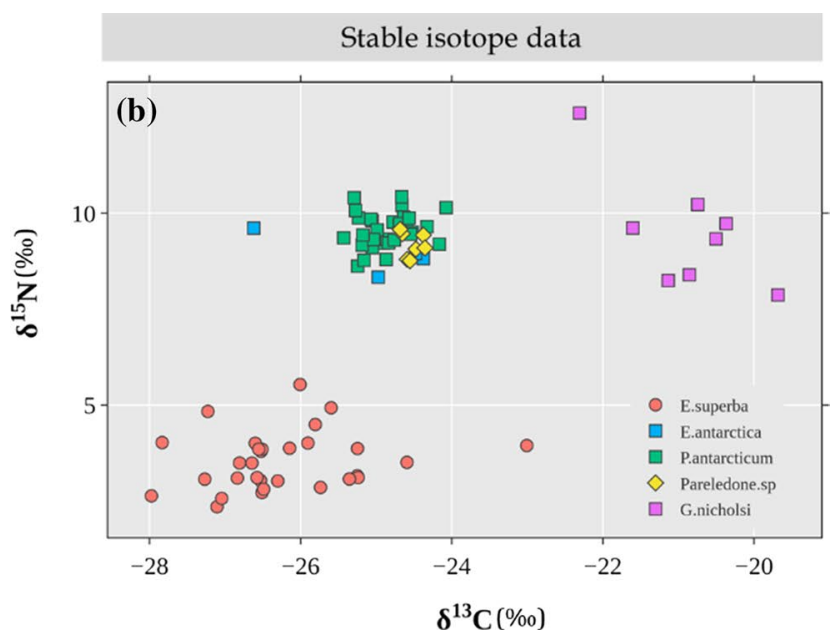

resent cephalopod species, whereas the circle symbol is krill. The fish species $P$. antarcticum and E. antarctica, and the cephalopod Pareledone sp., are isotopically very similar; therefore they were combined into a single group named $P a \_E a \_P$ for diet estimation

Table 3 Proportions of diet estimated for crabeater seals, by MixSIAR using fatty acid or stable isotope data

\begin{tabular}{lll}
\hline Sources & \multicolumn{2}{l}{ Diet estimation for crabeater seals } \\
\cline { 2 - 3 } & Fatty acids & Stable isotopes \\
\hline E. superba & $0.840(0.799-0.867)$ & $0.911(0.836-0.972)$ \\
E. carlsbergi & $0.012(0.001-0.042)$ & $0.041(0.002-0.125)$ \\
E. antarctica & $0.109(0.042-0.150)$ & - \\
$P$. antarcticum & $0.032(0.002-0.145)$ & - \\
$P a \_$Ea & - & $0.037(0.002-0.110)$ \\
\hline
\end{tabular}

The group "Pa_Ea" corresponds to the combined isotope values of the fish $P$. antarcticum and E. antarctica 

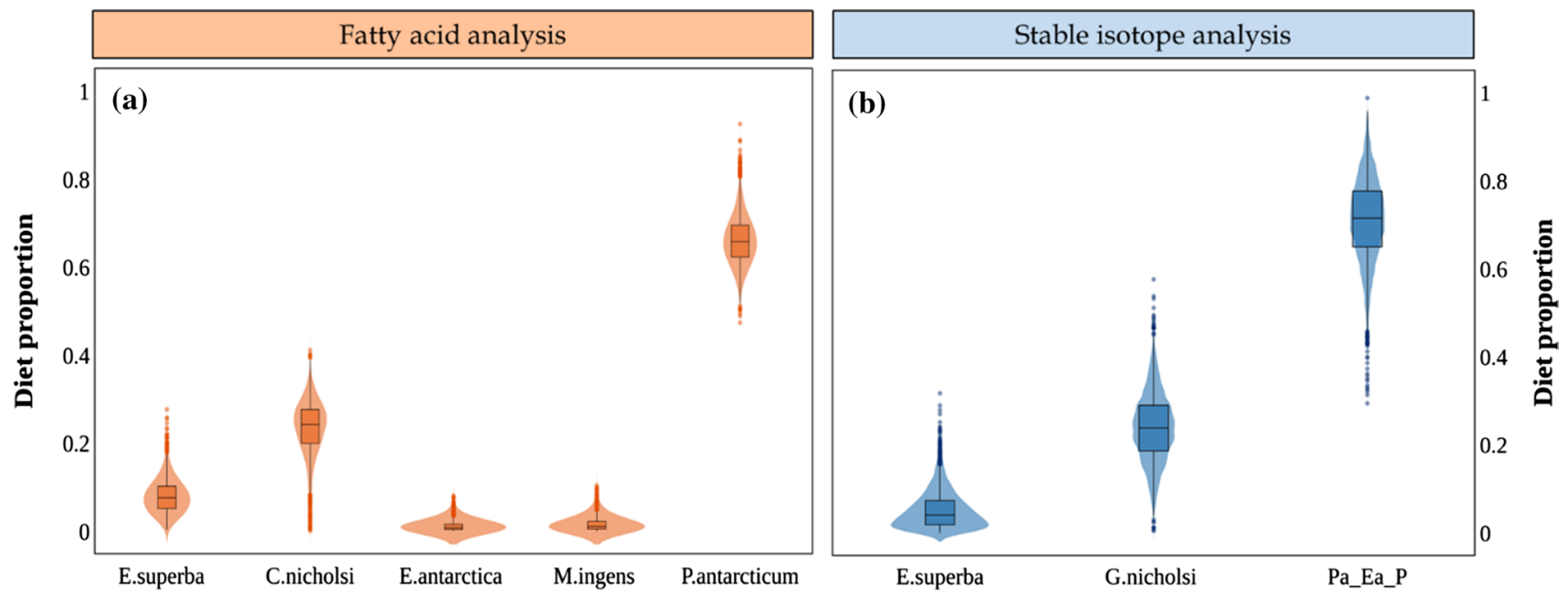

Fig. 5 Diet estimation for Weddell seals $(n=18)$ using the Bayesian mixing model MixSIAR, based on a fatty acid or $\mathbf{b}$ stable isotope data. The prey "Pa_Ea_P" corresponds to the isotopic values of $P$.

followed by G. nicholsi and E. superba, with $24 \%$ and $4 \%$, respectively (Table 3 , Fig. 5b).

\section{Diet estimation for leopard seals}

Pareledone sp. was used for the SI model and $M$. ingens for the FA model. Source species had different SI $\left(F_{4}=308.04\right.$, $P=0.001$, Fig. 6a) and FA values $\left(F_{4}=96.52, P=0.001\right.$, Fig, 6b), thus, all sources were used in the models (Table 2).

Both FA and SI models identified E. superba as the main component of the leopard seal's diet (Fig. 7). The antarcticum, E. antarctica and Pareledone sp, combined into a single group, due to their isotopic similarity

model based on FA data estimated that E. superba was $66 \%$ of their diet whereas the SI model estimation was $63 \%$ (Table 4). The FA model determined that the second most important source, with $19 \%$ contribution, was the Antarctic fur seal, A. gazella, followed by an $11 \%$ contribution from the Antarctic silverfish, P. antarcticum, and $3 \%$ from the gentoo penguin, $P$. рариа, whereas the cephalopod $M$. ingens was insignificant. Conversely, the SI model estimated the contribution of the four sources ( $A$. gazella, $P$. antarcticum, $P$. papua and $M$. ingens) as almost equal (between $6 \%$ and $8 \%$ ).
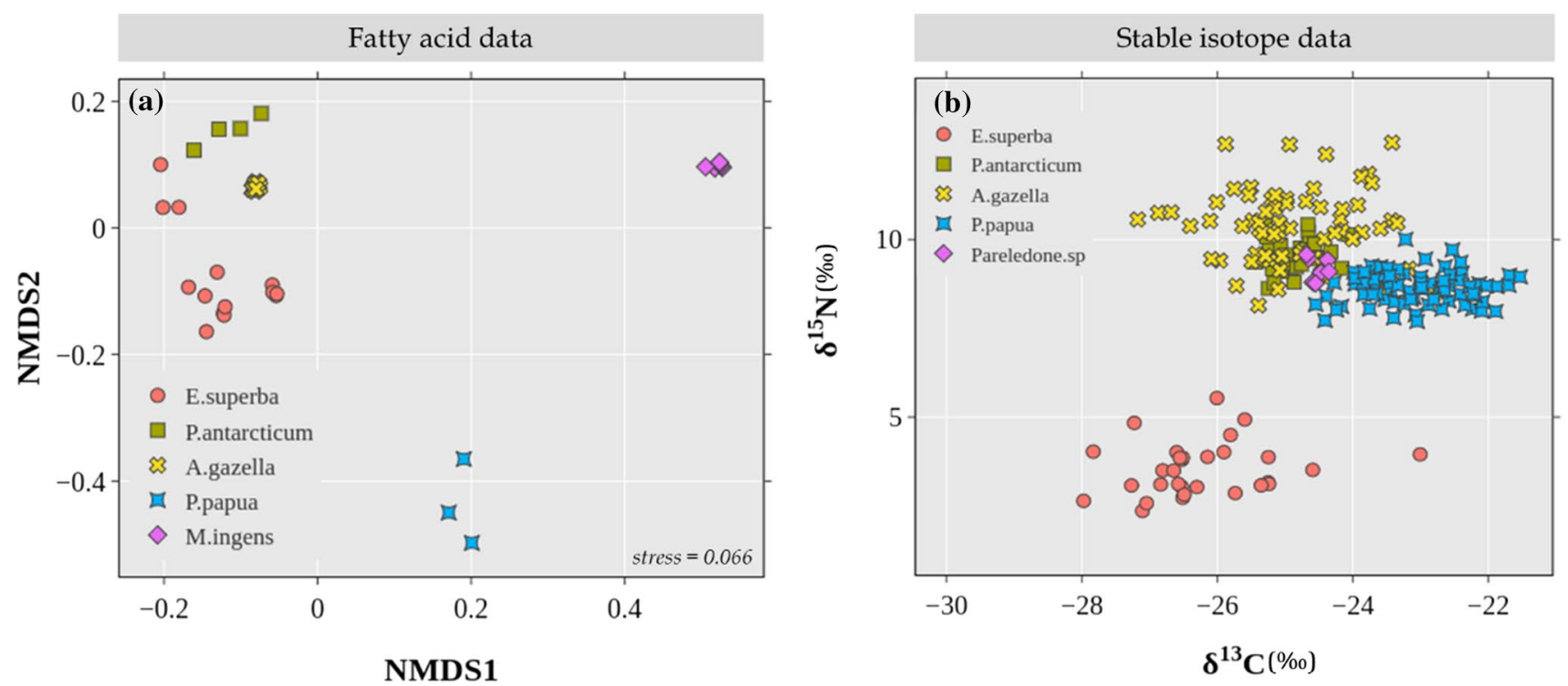

Fig. 6 Biplots for biotracer values of source species used to estimate the diet of leopard seals: a non-metric multi-dimensional scaling (NMDS) plot of their FA profiles, and $\mathbf{b}$ biplot of their isotopic values 


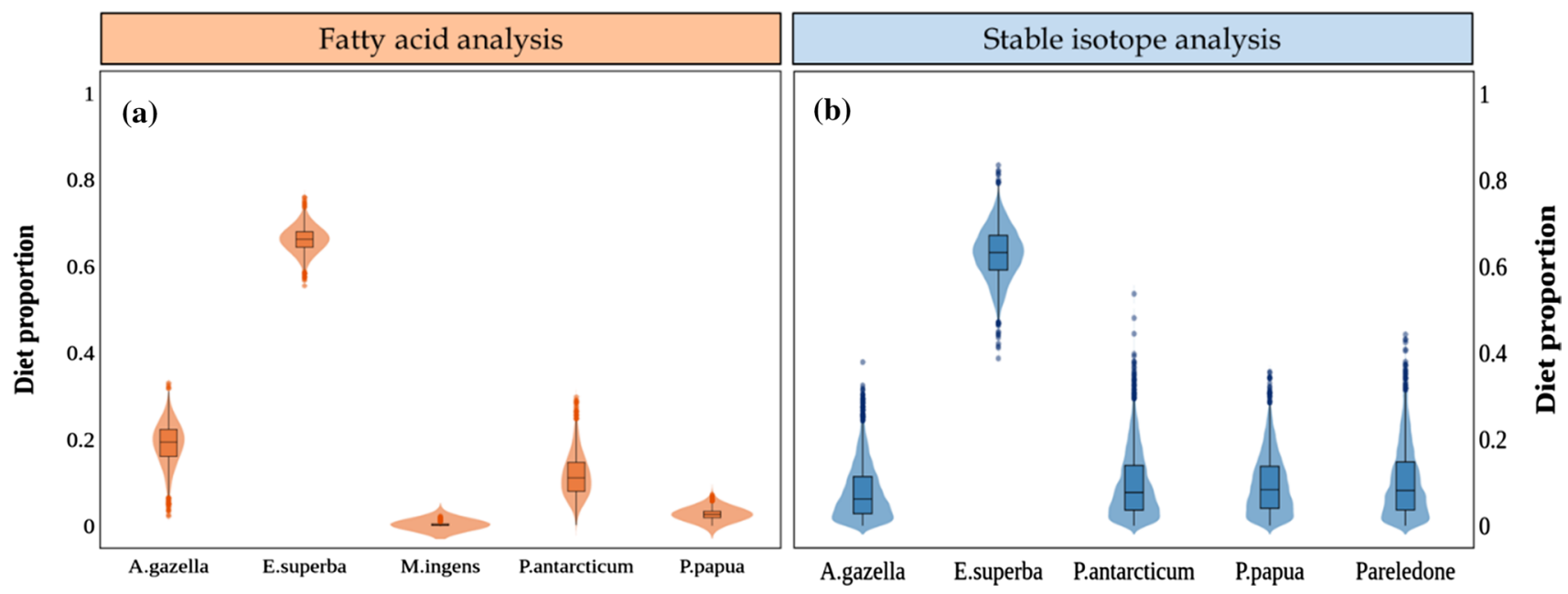

Fig. 7 Diet estimation for leopard seals $(n=13)$ using the Bayesian mixing model MixSIAR, based on a fatty acid or $\mathbf{b}$ stable isotope data

Table 4 Proportions of diet estimated for Weddell seals, using MixSIAR with fatty acid or stable isotope data

\begin{tabular}{lll}
\hline Sources & \multicolumn{2}{l}{ Diet estimation for Weddell seals } \\
\cline { 2 - 3 } & Fatty acids & Stable isotopes \\
\hline E. superba & $0.076(0.038-0.164)$ & $0.040(0.002-0.138)$ \\
E. antarctica & $0.008(0.000-0.039)$ & - \\
$P$. antarcticum & $0.657(0.558-0.782)$ & - \\
$M$. ingens & $0.011(0.000-0.057)$ & - \\
$P a \_$Ea_P & - & $0.715(0.496-0.860)$ \\
G. nicholsi & $0.242(0.080-0.338)$ & $0.238(0.085-0.373)$ \\
\hline
\end{tabular}

The group "Pa_Ea_P" correspond to the combined isotope values of the fish P. antarcticum and E. antarctica, and the squid Pareledone sp

\section{Discussion}

We show that models (using Bayesian tool MixSIAR) that use FA and SI data predict similar diets for three sympatric top predators with different foraging strategies. This approach, the combination of two different biotracers using the same quantitative statistical tool, has the potential to produce complementary diet estimates. To date, few studies have applied quantitative tools to both biotracers (e.g. Neubauer and Jensen 2015), and typically the complementary use of these two biotracers, FA and SI, has relied on the qualitative use of FA data (e.g. Hooker et al., 2001; Herman et al., 2005). FA data can be used quantitatively with a software tool broadly used with SI data. Recent application of MixSIAR to FA data has shown that this approach correctly identifies main diet components for captive animals with known diets (Guerrero and Rogers 2020) and herbivorous zooplankton using simulated FA data (Litmanen et al. 2020). We tested the FA approach
Table 5 Proportions of diet estimated for leopard seals, using MixSIAR with fatty acid or stable isotope data

\begin{tabular}{lll}
\hline Sources & \multicolumn{2}{l}{ Diet estimation for leopard seals } \\
\cline { 2 - 3 } & Fatty acids & Stable isotopes \\
\hline A. gazella & $0.194(0.084-0.275)$ & $0.062(0.002-0.232)$ \\
E. superba & $0.663(0.606-0.717)$ & $0.632(0.509-0.742)$ \\
P. antarcticum & $0.111(0.038-0.230)$ & $0.077(0.003-0.278)$ \\
P. papua & $0.027(0.006-0.050)$ & $0.083(0.004-0.250)$ \\
Pareledone sp & - & $0.081(0.002-0.300)$ \\
M. ingens & $0.003(0.000-0.012)$ & - \\
\hline
\end{tabular}

with wild predators and the results are comparable to those obtained using SIs, the biotracer most widely used for ecological studies (Table 5).

We do not expect to get identical diet predictions from models using SIs and FAs because the biotracers undergo different biochemical pathways and assimilate diet over potentially different time frames. In phocid seals, the SI in an entire vibrissae can represent diet assimilated for up to a year; where smaller sections of the vibrissae, can represent diet over days to weeks (Rogers et al. 2016). Rogers et al. (2016) measured the vibrissae growth and the rate of replacement of captive leopard seals and showed that vibrissae shed annually, and are lost asynchronously, thus, depending on when a vibrissae had been shed, it will represent growth (and so diet items assimilated) over weeks up to a year. Although the growth pattern of the vibrissae of the crabeater and Weddell seals are unknown, they are likely to represent diet assimilated over a similar timeframe to the leopard seal, as do other phocid seals (Hirons et al. 2001; Greaves et al. 2004; Newland et al. 2011; Beltran et al. 2015). 
The timeframe integrated by blubber FAs will depend on the blubber section (layer) analysed. In most marine mammals, including crabeater (Guerrero and Rogers 2017), leopard (Guerrero et al. 2016) and Weddell seals (Wheatley et al. 2007), blubber FAs are stratified. This implies that FAs in the outer layer (the half closer to the skin) are in different proportions compared to the inner layer (the half closer to the muscle). The dietary signal in the inner layer more closely reflects dietary FAs, as they are preferentially stored in this section (Koopman 2007; Guerrero et al. 2016). Conversely, the outer blubber layer is usually more stable and does not seem to respond to short-term shifts in diet or body condition (Struntz et al. 2004). Outer layer FAs, for example, maintain their composition during lactation in Weddell seals (Wheatley et al. 2007), and northern elephant seals (Fowler et al. 2014). However, although the proportion of FAs may differ between layers, the overall FA pattern is similar (Hooker et al. 2001); thus, the outer layer is thought to be an indicator of longer-term diet (Moller et al. 2003; Budge et al. 2006; Guerrero et al. 2020) compared to the inner layer that reflects from hours to months (Kirsch et al. 2000; Budge et al. 2004, 2006). Here, we used only the outer layer for FA analysis since it can be obtained remotely, hence, requires comparatively less effort and lower economic costs than the collection of whole blubber samples. Therefore, although both vibrissae and outer blubber integrate diet history over long timeframes (potentially months to years), they may not represent the exact same timescale.

\section{Comparison of estimated diets}

\section{Crabeater seals}

For the crabeater seal both SI and FA models identified krill as the main component of their diet, in agreement with previous studies (Laws 1977; Øritsland 1977; Green and Williams 1986; Lowry et al. 1988; Siniff 1991; Hückstädt et al. 2012; Botta et al. 2018). However, the FA model estimated krill to be a smaller contribution than the SI model $(84 \%$ and $91 \%$, respectively). Other studies based on SIs, have found krill to contribute $88 \%$ (Hückstädt et al. 2012) and $90 \%$ (Botta et al. 2018) to the diet of crabeater seals from the western Antarctic Peninsula. Similarly, studies based on conventional stomach and scat content analysis, which usually represent only summer diet, have found that crabeater seals can feed almost exclusively on krill (Laws 1977; Øritsland 1977), although the occasional occurrence of krill other than E. superba, octopus, and fish, in their food remains suggests that they display opportunistic feeding behaviour (Green and Williams 1986).

The slightly lower contribution of krill predicted by the FA model could be associated with an overestimation of sources containing higher proportions of fat. The lipid content of the fish species used as sources ranges from $\sim 32$ to $\sim 38 \%$ of dry weight (Hagen et al. 2000; Stowasser et al. 2009) whereas krill may range from $\sim 7 \%$ in winter to $17 \%$ in summer (Virtue et al. 1993; Hagen et al. 2001). Since the outer blubber layer reflects a long-term diet, which probably integrates periods where krill lipids are reduced to a minimum during winter and early spring (Ikeda and Dixon 1982; Hagen et al. 1996), the fat stores of the consumer are potentially reflecting better those sources with higher lipid content.

Little is known about the fish species consumed by crabeater seals. Here we included the same prey species used by Hückstädt et al. (2012), which correspond to fish species known to be consumed by other krill specialists, the Antarctic fur seal and the Adélie penguin Pygoscelis adeliae. For crabeater seals, only the Antarctic silverfish $P$. antarcticum has been identified in food remains (Green and Williams 1986; Lowry et al. 1988); however, Green and Williams, (1986) found that whereas 4 out of 45 otoliths were from $P$. antarcticum, the majority (41) were from non-identified fish, suggesting that this is not the primary fish consumed by crabeater seals.

Unlike SIs, FAs were able to separate all fish species, indicating that consumption of the myctophid fish $E$. antarctica was more important than the other fish species. The SI model; however, attributed a minor contribution to the group $\mathrm{Pa} \_\mathrm{Ea}$, composed by $E$. antarctica and $P$. antarcticum. However, without basal knowledge, it is difficult to determine whether the FA or the SI model provided a better prediction in this regard.

\section{Weddell seals}

Weddell seals feed primarily on fish (Siniff 1991); thus, we included several fish species that have been previously reported as their prey items. The FA model predicted that $P$. antarcticum was the most important item in their diet, whereas the SI model estimated that the group Pa_Ea_P; which included $P$. antarcticum, E. antarctica and the squid Pareledone sp; was the main component. Using SIs of blood and vibrissae of Weddell seals from the Ross Sea, Goetz et al. (2016) determined that the species group with the highest proportional contribution was that composed by $P$. antarcticum and Trematomus newnesi. Similarly, Botta et al. (2018) through SI analysis found that the fish group was the main contributor to the diet of Weddell seals from the western Antarctic Peninsula. Based on scat contents, Burns et al. (1998) found remains of $P$. antarcticum in 70-100\% of the scats analysed, with little temporal variation over five years of study in McMurdo Sound. Plötz (1986) found that this fish constituted $61 \%$ and $94 \%$ of all otoliths, in two different years of study, and Casaux et al. (2006) found that $P$. antarcticum was within the first three predominant fish 
species by mass, in two different years, based on scat content analysis of Weddell seals from Cierva Point; the same location where our seals were sampled. Thus, we could infer that the FA model correctly identified the most important fish species in the diet, although we cannot confirm that proportions are accurate. Conversely, the SI model did not provide the same taxonomic resolution due to the isotopic similarity among sources, even when they belonged to different taxonomic groups (fish and cephalopod). This is common when using SIs; thus, other studies have not been able to identify prey items to a species level (e.g. Goetz et al. 2016; Botta et al. 2018).

Both approaches identified G. nicholsi as the second most important dietary item, with the same percentage of contribution (24\%). According to scat content analyses of Weddell seals from the same study area (Casaux et al. 2006), $G$. nicholsi has a minor importance in their diet (between $\sim 2$ to $\sim 4 \%$ importance by mass). There are other potentially important species that we did not include due to unavailability of either SI or FA data, such as the Antarctic cod Dissostichus mawsoni (Plötz 1986; Siniff 1991), Trematomus species (Plötz 1986; Plötz et al. 1991; Burns et al. 1998; Casaux et al. 2006), and some channichthyid species (Plötz 1986; Plötz et al. 1991; Casaux et al. 2006). Therefore, these results should be interpreted with caution.

Krill is known to have less importance in the diet of Weddell seals compared to crabeater and leopard seals (Forcada et al. 2012). Our results concord with the SI-based study of Botta et al. (2018) and other content analysis studies that found that, although present, krill was not relevant in the diet of the Weddell seals (Casaux et al. 1997, 2006).

\section{Leopard seals}

Leopard seals have the broadest diet of the Antarctic packice seals, with krill, penguins, fish and other seals reported as the most frequent food items (Lowry et al. 1977; Øritsland 1977; Rogers and Bryden 1995; Krause and Rogers 2019; Krause et al. 2020). For leopard seals, we included the same five prey items for both FA and SI models. Krill was identified as the main component of the diet, and in similar proportions by the models that used the FA and SI data: $66 \%$ vs $63 \%$ respectively. Other studies in the same region also showed that krill was the most frequent and numerous prey found in leopard seal scats (Casaux et al. 2009), and according to SI data of vibrissae (Botta et al. 2018).

There are differences, however, between the models predictions of the importance of the other prey items. The model using SI data predicted an almost equal contribution of all other four sources, suggesting that leopard seals had a generalist diet. However, this could be due to the inability of the model to differentiate among prey items, since weakly informative data shifts the posterior distribution towards a generalist diet (i.e. the uninformative prior is really a generalist prior) (Stock and Semmens 2016). Conversely, FAs predicted a higher contribution of A. gazella, followed by $P$. antarcticum. The model using FA data potentially over represents the contribution of fur seals, since leopard seals prey on the fur seals between December and mid-February, when pups are 1-2 months old (Hiruki et al. 1999; Krause and Rogers 2019; Krause et al. 2020). Since the outer blubber reflects a long-term diet, the overall contribution of this prey species is expected to be smaller. Potentially, this is a limitation associated with the use of milk FAs as a proxy of pup FAs, since as seen in other pinniped species, blubber of pups does not exactly match that of the mother's milk or blubber (Grahl-Nielsen et al. 2000; Wheatley et al. 2008). Similarly, milk SIs might not be the ideal proxy for pup SIs, since pup blood is enriched in $\delta^{15} \mathrm{~N}$ and depleted in $\delta^{13} \mathrm{C}$ compared to milk (Cherel et al. 2015). However, in the absence of FA or SI data of Antarctic fur seal pups, this was the most representative solution.

\section{Implications for trophic studies}

Our results demonstrate that the application of the Bayesian tool MixSIAR to FA data provides dietary estimations comparable to those obtained from SI data. Indeed, the use of both approaches has an increased economic cost due to laboratory analyses, which is an important limitation to the study. FAs have greater power of distinction among prey species, allowing higher taxonomic resolution. We, therefore, recommend the use of this complimentary approach especially when prey species are isotopically similar.

Because FAs and SIs produced similar results, the use of either approach is also recommended for dietary studies. In this regard, and since SIs are already being broadly used for quantitative ecological studies, we promote the use of FA data as an alternative. It has been demonstrated that FA data, using MixSIAR, correctly identifies the main dietary items of captive fish, seals and birds (Guerrero and Rogers 2020). We demonstrate that diet estimates of wild marine mammals do not differ from those obtained from SI data, in fact, can provide clearer results by identifying prey to a species level.

Unlike the SI approach, the accuracy of diet estimation based on FA data can be affected by prey lipid content. Fatrich prey provides increased lipids for storage in the blubber; thus, diet estimation models based on blubber FAs can overestimate the contribution of prey with greater lipid content (Guerrero and Rogers 2020). We, therefore, recommend to determine lipid content for each prey species during the lipid extraction analysis. MixSIAR can account for prey lipid content by incorporating "concentration dependence" in the diet estimation model (Stock and Semmens 2013).

These analyses also demonstrate that the outer layer is a good proxy of long-term diet. It has been argued that the 
dietary signal is "erased" in the outer blubber layer and that inferences about diet should only been derived from the inner layer (Olsen and Grahl-Nielsen 2003). However, although the outer blubber has lower turnover rates than the inner layer (Budge et al. 2006), FAs from the diet are deposited into both layers, although in lower concentration in the outer section (Budge et al. 2004). Although more structural in nature (Budge et al. 2006; Guerrero and Rogers 2019), the outer blubber layer preserves valuable information of dietary history over long periods of time. This has important implications for field work, as the outer layer can be collected remotely, with minimum disturbance of the animal; making the use of blubber FAs more feasible for dietary studies. Additionally, this technique makes possible the simultaneous collection of, not only outer blubber, but skin and fur, which can be used for SI analysis.

Perhaps the weakest aspect of using these biotracers is how we account for trophic modification from source to consumer (Guerrero and Rogers 2020). Although controversial, the use of trophic discrimination derived from other consumer species is a common practice when using SIs quantitatively (e.g. Goetz et al. 2016; Sepúlveda et al. 2017). Since the quantitative use of FAs is more recent, only a few studies have used calibration coefficients derived from other consumer species (e.g. Thiemann et al. 2008). Rosen and Tollit (2012) warn against using calibration coefficients interchangeably, since they can be very species-specific. However, conducting feeding experiments to calculate the trophic modification for each study species is challenging, and for some species, not possible. Thus, the use of discrimination values derived from other species is a feasible alternative to estimate diets quantitatively.

Marine mammals integrate and reflect ecological variation across large spatial and long temporal scales (Moore 2008). Although their study is logistically challenging, new methodologies, like the approach we demonstrate here, allow us to generate quantitative data that is important to understand predator-prey dynamics on a long-term basis. Diet estimates of top predators are important to monitor ecosystem dynamics, as they can reflect changes occurring at lower trophic levels. Quantitative dietary data is also useful to understand conflicts between top predators and local fisheries, and in order to implement management programmes. Furthermore, dietary information is important to direct future research in wild populations and can be determinant to prioritise conservation.

Supplementary Information The online version contains supplementary material available at https://doi.org/10.1007/s00442-021-05045-z.

Acknowledgements We acknowledge the Bioanalytical Mass Spectrometry Facility within the Analytical Centre of the University of New South Wales, and particularly we thank Lewis Adler for his help with fatty acid analyses. We thank the Instituto Antártico Argentino; our work would have not been possible without their logistic support. A special thanks to the Mammal team at Base Primavera: Sebastián Poljak, Magalí Bobinac, Gastón Lo Coco, Juan Galliari and Pedro Carlini.

Author contribution statement $\mathrm{AG}, \mathrm{AP}, \mathrm{JN}$ and TR conceived and designed the study. AG and JN collected samples. AG and AP conducted laboratory analyses. AG analysed the data. AG and TR wrote the manuscript and all the authors revised and approved the final product.

Funding This study was funded by the Scott Foundation to TR, and FONDECYT Postdoctorado (3180433) to AG.

Availability of data and material All data produced from this study are available in this manuscript and the supplementary material.

Code availability We used the MixSIAR code from Stock et al. (2018) which is available at https://github.com/brianstock/MixSIAR

\section{Declarations}

Conflict of interest Authors declare no conflicts of interest.

Ethics approval All applicable institutional guidelines for the care and use of animals were followed and approved by UNSW Animal Care and Ethics Committee (Approval 15/55A).

Consent to participate Not applicable.

Consent for publication Not applicable.

Open Access This article is licensed under a Creative Commons Attribution 4.0 International License, which permits use, sharing, adaptation, distribution and reproduction in any medium or format, as long as you give appropriate credit to the original author(s) and the source, provide a link to the Creative Commons licence, and indicate if changes were made. The images or other third party material in this article are included in the article's Creative Commons licence, unless indicated otherwise in a credit line to the material. If material is not included in the article's Creative Commons licence and your intended use is not permitted by statutory regulation or exceeds the permitted use, you will need to obtain permission directly from the copyright holder. To view a copy of this licence, visit http://creativecommons.org/licenses/by/4.0/.

\section{References}

Acevedo J, Carreño E, Torres D et al (2015) Cephalopod remains in scats of Weddell seals (Leptonychotes weddellii) at Cape Shirreff, South Shetland Islands, Antarctica. Polar Biol 5:10. https://doi. org/10.1007/s00300-015-1713-0

Alonzo F, Virtue P, Nicol S, Nichols PD (2005) Lipids as trophic markers in Antarctic krill. II. Lipid composition of the body and digestive gland of Euphausia superba in controlled conditions. Mar Ecol Prog Ser. https://doi.org/10.3354/meps296065

Beck CA, Rea LD, Iverson SJ et al (2007) Blubber fatty acid profiles reveal regional, seasonal, age-class and sex differences in the diet of young Steller sea lions in Alaska. Mar Ecol Prog Ser 338:269-280 
Beltran RS, Sadou MC, Condit R et al (2015) Fine-scale whisker growth measurements can reveal temporal foraging patterns from stable isotope signatures. Mar Ecol Prog Ser 523:243-253

Botta S, Secchi ER, Rogers TL et al (2018) Isotopic niche overlap and partition among three Antarctic seals from the Western Antarctic Peninsula. Deep Res Part II Top Stud Oceanogr. https://doi.org/ 10.1016/j.dsr2.2017.11.005

Bromaghin JF (2017) qfasar: quantitative fatty acid signature analysis with R. Methods Ecol Evol. https://doi.org/10.1111/2041-210X. 12740

Budge SM, Cooper MH, Iverson SJ (2004) Demonstration of the deposition and modification of dietary fatty acids in pinniped blubber using radiolabelled precursors. Physiol Biochem Zool 77:682-687

Budge SM, Iverson SJ, Koopman HN (2006) Studying trophic ecology in marine ecosystems using fatty acids: a primer on analysis and interpretation. Mar Mammal Sci 22(4):759-801

Burns JM, Trumble SJ, Castellini MA, Testa JW (1998) The diet of Weddell seals in McMurdo Sound, Antarctica as determined from scat collections and stable isotope analysis. Polar Biol. https://doi. org/10.1007/s003000050245

Casaux R, Baroni A, Carlini A (1997) The diet of the Weddell seal Leptonychotes weddelli at Harmony point, South Shetland Islands. Polar Biol. https://doi.org/10.1007/s003000050202

Casaux R, Baroni A, Ramón A (2006) The diet of the Weddell Seal Leptonychotes weddellii at the Danco Coast, Antarctic Peninsula. Polar Biol. https://doi.org/10.1007/s00300-005-0048-7

Casaux R, Baroni A, Ramón A et al (2009) Diet of the Leopard Seal Hydrurga leptonyx at the Danco Coast, Antarctic Peninsula. Polar Biol. https://doi.org/10.1007/s00300-008-0567-0

Casaux R, Bertolin ML, Carlini A (2011) Feeding habits of three seal species at the Danco Coast, Antarctica: a re-assessment. Polar Biol. https://doi.org/10.1007/s00300-011-0994-1

Cherel Y, Hobson KA, Guinet C (2015) Milk isotopic values demonstrate that nursing fur seal pups are a full trophic level higher than their mothers. Rapid Commun Mass Spectrom 29:1485-1490

Clarke A, Murphy EJ, Meredith MP et al (2007) Climate change and the marine ecosystem of the western Antarctic Peninsula. Philos Trans R Soc B Biol Sci 362(1477):149-166

Dalsgaard J, St John M, Kattner G et al (2003) Fatty acid trophic markers in the pelagic marine environment. Adv Mar Biol 46:225-340

Fleming AH, Clark CT, Calambokidis J, Barlow J (2016) Humpback whale diets respond to variance in ocean climate and ecosystem conditions in the California Current. Glob Chang Biol. https://doi. org $/ 10.1111 / \mathrm{gcb} .13171$

Folch J, Lees M, Stanley S (1957) A simple method for the isolation and purification of total lipides from animal tissues. J Biol Chem 226:497-509

Forcada J, Trathan PN, Boveng PL et al (2012) Responses of Antarctic pack-ice seals to environmental change and increasing krill fishing. Biol Conserv 149:40-50. https://doi.org/10.1016/j.biocon. 2012.02.002

Fowler MA, Debier C, Mignolet E et al (2014) Fatty acid mobilization and comparison to milk fatty acid content in northern elephant seals. J Comp Physiol B Biochem Syst Environ Physiol. https:// doi.org/10.1007/s00360-013-0787-7

Fricke H, Gercken G, Schreiber W, Oehlenschläger J (1984) Lipid, sterol and fatty acid composition of Antarctic krill (Euphausia superba Dana). Lipids 19:821-827

Gales NJ, Cheal AJ (1992) Estimating diet composition of the Australian sea-lion (Neophoca cinerea) from scat analysis: an unreliable technique. Wildl Res. https://doi.org/10.1071/WR9920447

Gannes LZ, O'Brien DM, Del Rio CM (1997) Stable isotopes in animal ecology: assumptions, caveats, and a call for more laboratory experiments. Ecology 78:1271-1276
Gelman A, Carlin JB, Stern HS et al (2014) Bayesian data analysis. Taylor \& Francis, Boca Raton

Geweke J (1991) Evaluating the accuracy of sampling-based approaches to the calculation of posterior moments. Federal Reserve Bank of Minneapolis, Research Department Minneapolis

Goetsch C, Conners MG, Budge SM et al (2018) Energy-rich mesopelagic fishes revealed as a critical prey resource for a deep-diving predator using quantitative fatty acid signature analysis. Front Mar Sci 5:430

Goetz KT, Burns JM, Hückstädt LA et al (2016) Temporal variation in isotopic composition and diet of Weddell seals in the western Ross Sea. Deep Res Part II Top Stud Oceanogr. https://doi.org/ 10.1016/j.dsr2.2016.05.017

Grahl-Nielsen O, Hammill MO, Lydersen C, Wahlstrøm S (2000) Transfer of fatty acids from female seal blubber via milk to pup blubber. J Comp Physiol B Biochem Syst Environ Physiol. https:// doi.org/10.1007/s003600000099

Grahl-Nielsen O, Haug T, Lindstrøm U, Nilssen KT (2011) Fatty acids in harp seal blubber do not necessarily reflect their diet. Mar Ecol Prog Ser 426:263-276. https://doi.org/10.3354/meps09011

Greaves DK, Hammill MO, Eddington JD et al (2004) Growth rate and shedding of vibrissae in the gray seal, Halichoerus grypus: a cautionary note for stable isotope diet analysis. Mar Mammal Sci. https://doi.org/10.1111/j.1748-7692.2004.tb01158.x

Green K, Williams R (1986) Observations on food remains in faeces of elephant, leopard and crabeater seals. Polar Biol 6:43-45. https:// doi.org/10.1007/BF00446239

Guerrero AI, Rogers TL (2017) Blubber fatty acid composition and stratification in the crabeater seal, Lobodon carcinophaga. J Exp Mar Bio Ecol 491:51-57

Guerrero AI, Rogers TL (2019) From low to high latitudes: changes in fatty acid desaturation in mammalian fat tissue suggest a thermoregulatory role. BMC Evol Biol 19:155

Guerrero AI, Rogers TL (2020) Evaluating the performance of the Bayesian mixing tool MixSIAR with fatty acid data for quantitative estimation of diet. Sci Rep. https://doi.org/10.1038/ s41598-020-77396-1

Guerrero AI, Negrete J, Márquez MEI et al (2016) Vertical fatty acid composition in the blubber of leopard seals and the implications for dietary analysis. J Exp Mar Bio Ecol 478:54-61

Guerrero AI, Pavez G, Santos-Carvallo M et al (2020) Foraging behaviour of the South American sea lion (Otaria byronia) in two disparate ecosystems assessed through blubber fatty acid analysis. Sci Rep 10:1-13

Hagen W, Van Vleet ES, Kattner G (1996) Seasonal lipid storage as overwintering strategy of Antarctic krill. Mar Ecol Prog Ser. https://doi.org/10.3354/meps134085

Hagen W, Kattner G, Friedrich C (2000) The lipid compositions of high-Antarctic notothenioid fish species with different life strategies. Polar Biol. https://doi.org/10.1007/s003000000153

Hagen W, Kattner G, Terbrüggen A, Van Vleet ES (2001) Lipid metabolism of the antarctic krill Euphausia superba and its ecological implications. Mar Biol. https://doi.org/10.1007/s002270000527

Hall-Aspland SA, Rogers TL (2004) Summer diet of leopard seals (Hydrurga leptonyx) in Prydz Bay, Eastern Antarctica. Polar Biol 5:10. https://doi.org/10.1007/s00300-004-0662-9

Hazen EL, Abrahms B, Brodie S et al (2019) Marine top predators as climate and ecosystem sentinels. Front Ecol Environ. https://doi. org/10.1002/fee. 2125

Herman DP, Burrows DG, Wade PR et al (2005) Feeding ecology of eastern North Pacific killer whales Orcinus orca from fatty acid, stable isotope, and organochlorine analyses of blubber biopsies. Mar Ecol Prog Ser 302:275-291

Higgins DP, Rogers TL, Irvine AD, Hall-Aspland SA (2002) Use of midazolam/pethidine and tiletamine/zolazepam combinations for 
the chemical restraint of leopard seals (Hydrurga leptonyx). Mar Mammal Sci. https://doi.org/10.1111/j.1748-7692.2002.tb01050.x

Hirons AC, Schell DM, Finney BP (2001) Temporal records of $\delta 13 \mathrm{C}$ and $\delta 15 \mathrm{~N}$ in North Pacific pinnipeds: inferences regarding environmental change and diet. Oecologia. https://doi.org/10.1007/ s004420100756

Hiruki LM, Schwartz MK, Boveng PL (1999) Hunting and social behaviour of leopard seals (Hydrurga leptonyx) at Seal Island, South Shetland Islands, Antarctica. J Zool. https://doi.org/10. 1017/S0952836999009097

Hooker S, Iverson S, Ostrom P, Smith S (2001) Diet of northern bottlenose whales inferred from fatty-acid and stable-isotope analyses of biopsy samples. Can J Zool 79:1442-1454

Hückstädt LA, Burns JM, Koch PL et al (2012) Diet of a specialist in a changing environment: the crabeater seal along the western Antarctic Peninsula. Mar Ecol Prog Ser. https://doi.org/10.3354/ meps09601

Ikeda T, Dixon P (1982) Body shrinkage as a possible over-wintering mechanism of the Antarctic krill, Euphausia superba Dana. J Exp Mar Biol Ecol. https://doi.org/10.1016/0022-0981(82)90088-0

Iverson SJ (1993) Milk secretion in marine mammals in relation to foraging: can milk fatty acids predict diet. In: Symp zool soc lond, pp 263-291

Iverson SJ, Arnould JPY, Boyd IL (1997) Milk fatty acid signatures indicate both major and minor shifts in the diet of lactating Antarctic fur seals (Arctocephalus gazella). Can J Zool 75(2):188-197

Iverson SJ, Field C, Bowen WD, Blanchard W (2004) Quantitative fatty acid signature analysis: a new method of estimating predator diets. Ecol Monogr. https://doi.org/10.1890/02-4105

Kirsch PE, Iverson SJ, Bowen WD (2000) Effect of a low-fat diet on body composition and blubber fatty acids of captive juvenile harp seals (Phoca groenlandica). Physiol Biochem Zool 73:45-59

Koopman HN (2007) Phylogenetic, ecological, and ontogenetic factors influencing the biochemical structure of the blubber of odontocetes. Mar Biol. https://doi.org/10.1007/s00227-006-0489-8

Krause DJ, Rogers TL (2019) Food caching by a marine apex predator, the leopard seal (Hydrurga leptonyx). Can J Zool. https://doi.org/ 10.1139/cjz-2018-0203

Krause DJ, Goebel ME, Kurle CM (2020) Leopard seal diets in a rapidly warming polar region vary by year, season, sex, and body size. BMC Ecol 20:1-15

Laws RM (1977) Seals and whales of the Southern Ocean. Philos Trans R Soc Lond B Biol Sci. https://doi.org/10.1098/rstb.1977.0073

Litmanen JJ, Perälä TA, Taipale SJ (2020) Comparison of Bayesian and numerical optimization-based diet estimation on herbivorous zooplankton. Philos Trans R Soc B 375:20190651

Lowry LF, Frost KJ, Burns JJ (1977) Trophic relationships among ice inhabiting phocid seals. In: Environmental assessment of the Alaskan continental shelf. Annual reports of principal investigators for the year ending March 1977, vol 1. Receptors-Mammals

Lowry LF, Testa JW, Calvert W (1988) Notes on winter feeding of crabeater and leopard seals near the Antarctic Peninsula. Polar Biol. https://doi.org/10.1007/BF00264724

Martinez Arbizu P (2017) pairwiseAdonis: pairwise multilevel comparison using adonis. R Packag version 001

McMeans BC, Arts MT, Fisk AT (2012) Similarity between predator and prey fatty acid profiles is tissue dependent in Greenland sharks (Somniosus microcephalus): implications for diet reconstruction. $\mathrm{J}$ Exp Mar Biol Ecol. https://doi.org/10.1016/j.jembe.2012.06.017

Mincks SL, Smith CR, Jeffreys RM, Sumida PYG (2008) Trophic structure on the West Antarctic Peninsula shelf: detritivory and benthic inertia revealed by $\delta 13 \mathrm{C}$ and $\delta 15 \mathrm{~N}$ analysis. Deep Sea Res Part II Top Stud Oceanogr 55:2502-2514

Moller P, Born EW, Dietz R et al (2003) Regional differences in fatty acid composition in common minke whales (Balaenoptera acutorostrata) from the North Atlantic. J Cetacean Res Manag 5(2):91
Moore SE (2008) Marine mammals as ecosystem sentinels. J Mammal 89(3):534-540

Neubauer P, Jensen OP (2015) Bayesian estimation of predator diet composition from fatty acids and stable isotopes. PeerJ 3:e920

Newland C, Field IC, Cherel Y et al (2011) Diet of juvenile southern elephant seals reappraised by stable isotopes in whiskers. Mar Ecol Prog Ser. https://doi.org/10.3354/meps08769

Newsome SD, Clementz MT, Koch PL (2010) Using stable isotope biogeochemistry to study marine mammal ecology. Mar Mammal Sci 26(3):509-572

Oksanen J, Blanchet FG, Friendly M et al (2018) vegan: Community Ecology Package. R package version 2.5-2

Olsen E, Grahl-Nielsen O (2003) Blubber fatty acids of minke whales: Stratification, population identification and relation to diet. Mar Biol. https://doi.org/10.1007/s00227-002-0934-2

Øritsland T (1977) Food consumption of seals in the Antarctic pack ice. In: Adaptations within Antarctic ecosystems

Phillips KL, Jackson GD, Nichols PD (2001) Predation on myctophids by the squid Moroteuthis ingens around Macquarie and Heard Islands: stomach contents and fatty acid analyses. Mar Ecol Prog Ser. https://doi.org/10.3354/meps215179

Phleger CF, Nelson MM, Mooney BD, Nichols PD (2002) Interannual and between species comparison of the lipids, fatty acids and sterols of Antarctic krill from the US AMLR Elephant Island survey area. Comp Biochem Physiol B Biochem Mol Biol. https://doi. org/10.1016/S1096-4959(02)00021-0

Plötz J (1986) Summer diet of Weddell Seals (Leptonychotes weddelli) in the eastern and southern Weddell Sea, Antarctica. Polar Biol. https://doi.org/10.1007/BF00258259

Plötz J, Ekau W, Reijnders PJH (1991) Diet of Weddell seals Leptonychotes weddellii at Vestkapp, Eastern Weddell Sea (Antarctica), in relation to local food supply. Mar Mammal Sci. https:// doi.org/10.1111/j.1748-7692.1991.tb00560.x

Polito MJ, Goebel ME (2010) Investigating the use of stable isotope analysis of milk to infer seasonal trends in the diets and foraging habitats of female Antarctic fur seals. J Exp Mar Biol Ecol. https:// doi.org/10.1016/j.jembe.2010.08.015

Polito MJ, Lynch HJ, Naveen R, Emslie SD (2011) Stable isotopes reveal regional heterogeneity in the pre-breeding distribution and diets of sympatrically breeding Pygoscelis spp penguins. Mar Ecol Prog Ser. https://doi.org/10.3354/meps08863

Rogers T, Bryden MM (1995) Predation of adelie penguins (Pygoscelis adeliae) by leopard seals (Hydrurga leptonyx) in Prydz Bay Antarctica. Can J Zool. https://doi.org/10.1139/z95-119

Rogers TL, Fung J, Slip D et al (2016) Calibrating the time span of longitudinal biomarkers in vertebrate tissues when fine-scale growth records are unavailable. Ecosphere 7:e01449

Rosen DAS, Tollit DJ (2012) Effects of phylogeny and prey type on fatty acid calibration coefficients in three pinniped species: implications for the QFASA dietary quantification technique. Mar Ecol Prog Ser 467:263-276

RStudio Team (2016) RStudio: integrated development for R

Sepúlveda M, Pavez G, Santos-Carvallo M et al (2017) Spatial, temporal, age, and sex related variation in the diet of South American sea lions in southern Chile. Mar Mammal Sci 33:480-495

Siniff DB (1991) An overview of the ecology of Antarctic seals. Integr Comp Biol. https://doi.org/10.1093/icb/31.1.143

Siniff DB, Stone S (1985) The role of the leopoard seal in the trophodynamics of the Antarctic marine ecosystem. In: Antarct nutr cycles food webs

Stock BC, Semmens BX (2013) MixSIAR GUI user manual, version 1.0. http//conserver iugo-cafe org/user/brice semmens/MixSIAR

Stock BC, Semmens BX (2016) Unifying error structures in commonly used biotracer mixing models. Ecology 97:2562-2569 
Stock BC, Jackson AL, Ward EJ et al (2018) Analyzing mixing systems using a new generation of Bayesian tracer mixing models. PeerJ. https://doi.org/10.7717/peerj.5096

Stowasser G, Pond DW, Collins MA (2009) Using fatty acid analysis to elucidate the feeding habits of Southern Ocean mesopelagic fish. Mar Biol. https://doi.org/10.1007/s00227-009-1256-4

Stowasser G, Atkinson A, McGill RAR et al (2012) Food web dynamics in the Scotia Sea in summer: a stable isotope study. Deep Res Part II Top Stud Oceanogr. https://doi.org/10.1016/j.dsr2.2011. 08.004

Struntz DJ, McLellan WA, Dillaman RM et al (2004) Blubber Development in Bottlenose Dolphins (Tursiops truncatus). J Morphol. https://doi.org/10.1002/jmor.10154

Thiemann GW, Iverson SJ, Stirling I (2008) Polar bear diets and arctic marine food webs: Insights from fatty acid analysis. Ecol Monogr. https://doi.org/10.1890/07-1050.1
Virtue P, Nichols P, Nicol S (1993) The lipid composition of Euphausia superba Dana in relation to the nutritional value of Phaeocystis pouchetii (Hariot) Lagerheim. Antarct Sci 5(02):169-177

Wheatley KE, Nichols PD, Hindell MA et al (2007) Temporal variation in the vertical stratification of blubber fatty acids alters diet predictions for lactating Weddell seals. J Exp Mar Biol Ecol. https:// doi.org/10.1016/j.jembe.2007.07.005

Wheatley KE, Nichols PD, Hindell MA et al (2008) Differential mobilization of blubber fatty acids in lactating weddell seals: evidence for selective use. Physiol Biochem Zool. https://doi.org/10.1086/ 590397

Zhao L, Castellini MA, Mau TL, Trumble SJ (2004) Trophic interactions of Antarctic seals as determined by stable isotope signatures. Polar Biol. https://doi.org/10.1007/s00300-004-0598-0 